\title{
English in Bangladesh: A Post-Colonial Sociolinguistic Observation
}

\author{
Abdul Awal \\ DOI: 10.29322/IJSRP.9.09.2019.p9390 \\ http://dx.doi.org/10.29322/IJSRP.9.09.2019.p9390
}

\begin{abstract}
This paper outlines the principal reason of the highest emergence of English language in Bangladesh with many recent sociolinguistic views critically. It also endeavors to draw the impact of English as international language on native language and culture. Some findings and proposal are illustrated based on the global history and politics of language. The relation between language and socio-cultural existence has got priority in this observation. Hopefully the paper will help people think English in a different look in socio-cultural and political life in post-colonial countries. This paper would be conducive to make future language policy of post-colonial countries. How language determines cultural and linguistic hegemony is notified vividly. Some suggestions for English language teachers in post-colonial countries including Bangladesh based on the recent sociolinguistics views on linguistics imperialism are proposed.
\end{abstract}

Index Terms- Prospero Complex, Caliban Complex, Grassroots Theory, Exploitation Theory, Linguistic Imperialism, Linguicism, Linguistic Chauvinism, Linguistic Human Rights, Para-Diglossia.

\section{INTRODUCTION}

L anguage is one of the most unique and powerful endowments to human beings. It is not only a medium of communication nut also a way of life and thinking. It determines the way a people look the world too. It bears the socio-cultural identity and experiences, knowledge and beliefs of an individual community. Due to the British colonial expansion, English language has occupied an important linguistic position in post-colonial countries. In sociolinguistics perspective, the spread of English in non-native countries is explained and criticized in different point of views. The impacts of emergence of English are also heightened because language is closely associated with human culture, views, identity and thinking. Sometimes, it is often called language determines our thinking and views to the world (Sapir Whorf hypothesis). Though there are many controversial issues too about it.

\section{PROSPERRO COMPLEX:}

In William Shakespeare's famous play, The Temper' (1610), Prospero is the protagonist of the play. He was the Duke of Milan who was forced to live in a desolate island with his daughter Miranda. He lived in the Island in twelve year. He owned magical powers. Here, he found a local boy named Caliban. He made Caliban his servant and taught him (Caliban) his language. Miranda was the daughter of Prospero. She did not see any other human without her father earlier. They misunderstood claiming that Caliban tried to rape her. They thought the Caliban was antagonistic towards Prospero as they ruled him after capturing it from him. So, Prospero illustrated Caliban as a malevolence character man erroneously. Interestingly, Shakespeare wrote this play in the region of Queen Elizabeth when British started to discover new lands everyday including India and America, besides they started to march on colonization. It is thought that Shakespeare was very much aware and far-sighted about the feature of colonization and thus he drew the attribute of political and linguistic imperialism in this play with an objective view.

Here, readers find that Prospero was the colonizer in the island. He tried to impose his language to the native. Besides, Caliban is the colonized who was oppressed by the linguistic and cultural imperialism by Prospero. The Term 'Prospero Complex' was the coined by D.O Mannoni in his 'Prospero and Caliban: The Psychology of Colonization' published in 1964. He drew the views and perception of colonizer towards the native speakers of colonized countries psychologically and culturally. As Prospero always thought that Caliban was uncultured and wild like his language, colonizers always think that native people are savage. Prospero was scared that Caliban might rape his daughter. The negative and mean attitude of colonizers towards the colonized people and their culture are entitled as Prospero Complex. It leads them strongly to dominate native people linguistically and culturally. For example, we can cite the famous noble of Daniel Defoe named 'Robinson Crusoe'. Here Robinson took shelter in an island and started to colonize over the land people. He found a native man whom began to teach English the first word he taught was 'master'. By linguistic imperialism, colonizers bear the dream to be a master of native people culturally, economically and politically. Before, learning the language of colonizer, they consider natives as savage; this view can be entitled Prospero Complex. The rapid spread of English after British colonization is often regarded as the consequence of Prospero Complex.

The English Education Act was a legislative Act of the council of India is 1835 giving effect to a decision in 1835 by William Bentinck, $4^{\text {th }}$ Duke of Portland, the then Governor General of British India to reallocate funds the East India Company was required by the British parliament to spend on education and literature in India ( Wikipedia). It made the people of India learn English as a medium of education. The people of Bangladesh were also under this ordinance. The medium of education in British colonial period was in English. McLeay asserted the reason to make ordinance English as a medium of education stating, 'Whether we look at the intrinsic value of our literature or at the particular situation of their country we shall 
see the strongest reason to think that, of all foreign tongue is the most useful to our native subjects. '(McLeay)

Though there were a lot of debates about learning English of a medium of education in British colonial period. In Bangladesh in the period of Pakistan Government, English was the Lingua Franca to communicate within the east and West Pakistan as they both belong to different mother tongue Bengali and Urdu. After independence, English Became a compulsory subject in education both Bengali medium including now in Madrasa education too. According to the report of English in Action, most sectors in Bangladesh require some degree of English in banking; It retails sectors demanding the most English speakers. 20\% of companies require a basic level of English. 38\% require intermediate level of English and a basic $38 \%$ require general knowledge of English. At present in Bangladesh, English is presented and involved as a major subject in our curriculum. Like other colonized countries, the people or learners who can speak well are considered highly educated thought they don't belong to any unique intellectually and knowledge. The people who belong to intellectuality and unique knowledge but having no acquisition of English are considered inferior. So English appears always with a domain face in schooling in Bangladesh like other countries of Indian subcontinent. To evaluate people based on their language, not on their intellectuality, is associated to Prospero Complex. That's why Fishman (1989) asserted this, 'Education is a socializing institution and must never be examined without concentrating on the social processes that it serves and the social pressure to which it responds'.

\section{CALIBAN COMPLEX:}

'Caliban Complex' is also called dependency complex. It deals with the inferiority complex of the colonized people. It makes a limitation psychologically inside the colonized people. In 'The Tempest', Shakespeare portrayed the dilemma and complexity of Caliban vividly. The Dependency Complex of colonized people leads the way to spread English over aboriginal people. In The Tempest by William Shakespeare, Prospero tried to make Caliban dependent to him by his magic. Making dependence helps colonizer to colonize native people. In the contexts of Bangladesh, People got independence politically, but they did not come out of Dependency Complex. People of Bangladesh have established an idea that without the language of dominating country, they can not cope with development and advancement. As a result, they give little attention to enrich their aboriginal language. Post- modern theorist and critic Frantz Fanon wrote excellently. 'Every colonized people in other words, every people in whose soul an inferiority complex has been created by the death and buried its local cultural originality - finds itself face to face with the language of the civilizing nation; that is with the culture of the mother country'. It is notified that Bangladesh People often feel inferiority complex for their native Bengali language this trend will maker a permanent dependence on speaker's Bengali language.

English language teaching in Bangladesh is not a new phenomenon. English has been practiced as a contact language for international and intra -national communication. It paved the way Indian sub-continent to accept and adopt English as the medium of education. Mahatma Gandhi (1869-1948) asserted in colonial period that offering knowledge of English to millions of people in the Indian sub- continent will just enslaved them. Gandhi, logically, protested. 'The medium of a foreign language thorough which higher education has been imparted in India has caused incalculable intellectual and moral injury to the nation'.Gandhi predicated that Indian people might be enslaved politically and cultural by learning English language because ;language is not only a medium of communication but also a medium of thinking an viewing the world.

The term 'English as a Lingua Franca' appears as an element to make empire to many cities. In Bangladesh like many others countries of Indian sub-continent, English is grandly learned by the name of Lingua Franca. Edward Said was a professor of literature al Columbia University, a public intellectual, and a founder of the academic field of postcolonial studies criticizing, 'The lingua Franca for metropolitan Britain: global Comprehensive and with so vats a social author as to be accessible to anyone speaking to and about the nation. This Lingua Franca locates England at the focal point of a world also resided over by its power, illuminated by its ideas and culture, kept productive by the attitudes of its moral teachers, artist, legislators (Culture and Imperialism). This term is making Euro-centric views of the entire world by the expansion of English. In 1992, a prominent sociolinguist published a book titling Linguistic Imperialism from Oxford University Press (OUP) where he launched the term LINGUISTIC IMPERIALISM to break the ice of considering English as lingua franca and the impacts of it in colonial and minor language community linguistically and socially. Phillips on also bravely and broadly drew the picture of domination and attitude of imported language speaker and community by the several the international. He illustrated the crucial mission of dominating countries to make a wide range and depth of their language to the different corners of the world. $\mathrm{He}$ linked the relation within the spread of English and the benefits of English speaking countries politically, culturally and economically if English becomes a lingua franc permanently.

\section{GRASSROOTS THEORY:}

In 1996, Fishman, Conroad and Rubal-Lopez jointly published a book of essays, named "Post-imperial English" where Fishman mainly installed theory called "GRASSROOTS THEORY" to explain the reason of wildfire spreading of English in post colonial countries including Bangladesh, India, Africa etc. He Introduces the reasons of spreading English by world political, Cultural and economic fields. The theory asserts the reason of spreading English is just for maintaining a lingua franca and to be connected with globalizing, modernization and progressive advancement in the present world, According to the Oxford Handbook. Of Sociolinguistics (2013) by Robert Beyley, Richard Cameron and Seil Laucs, 'The main argument of the Grassroots Theory is that the spread of English in the world today is not the product of British and American conspiracy'. Grassroots theory makes the legitimacy of using English by the excuse of internationalism and globalization. In Bangladesh, people learn English from the British period to present day to change their lot. English has ensured their economic solvency by learning English. Dr. Human Azad (1998) wrote the reason of speeding English in Bangladesh in British period, 'Bengali people did not 
learn English due to the divulgence of the estheticism of English literature; they rather learn English by the sake of their bread and butter. Before the Palashi War, some advanced Bengali people had learnt English and thus they made business collaboration with English as well as earning a lot of silver coin'. This is the implication of grassroots theory of the expansion of English language in Bangladesh as well as other post-colonial countries.

\section{EXPLOITATION THEORY :}

EXPLOITATION THEORY is another perception about the spreading of English language in the entire world especially the post colonial countries. EXPLOITATION THEORY claims that English is imposed in all over the world by the colonial masters for their own benefit ecumenically, culturally and politically in deep. So it imposed to make the colonized people enslave. Kandiah (2001) opined that when colonizer imposed their language to the native people. It makes a tense among the aboriginal people of the particular land. These are as a) colonized people need to learn English to be globalised and modernized as well as international communication continuum, b) they face a threat and confusion to be detached from their identity and ethnicity as imported language s always powerful politically and economically in consequence; linguistic and cultural imperialism will be naturally appeared cities often make satire ELT (English language Teaching) practitioners of local countries, "Army of Language missionaries."

LINGUISTIC IMPERIALISM is very much closely associated with exploitation theory of spreading English Linguistic imperialism stands for a dominant nation's practice of transferring its culture, social, political and even economical feature and ideologies by transferring its language to other nations. 'The spread of English is the result of a deliberate imperialist policy (Robert Phillipson, 1992). Linguistic imperialism is an exact phenomenon. It is very much predicted that the language of less powerful nation. Historically it is highly noticed from the ancient period to till now. In first to fourth century, Latin dominated over Roman Empire because they were politically, economical powerful in all over the Europe.

The idea of diglossia was coined by Ferguson (1959). It describes a situation where two language or language varieties happen side by side in a community, and each has a clear variety of functions. Diglossia in sociolinguistics in a term used to mean a speech community who speaks a language with prestigious $(\mathrm{H}-$ variety) and another language in less prestigious function (Lvariety). When a powerful nation makes colonization or domination politically, diglossic situation often happen. An overlapping and exaggeration in the practice of English Language teaching in Bangladesh might be predicted as to turn a diglossic situation. Diglossia is differed as function distinction of more than one language within a speech community. A present distinction of language in Bangladesh is noticed. Young adults use frequently English. English is public communication and media making functional distinction of language. English appears to them as a prestigious term-beside native language is considered less prestigious to them. It is noticed that from the very beginning to present day. English speaker in social function in Bengali have got supreme prestige and position in society. For example, we can mention the statement of Seventh Sastri who was a scholars, religious reformer, educator, writer and historian. He cited the position of Bengali people, who could speak English in British period, 'As they could speak and write English ungrammatically and without prosper structure, they got highest prestige and power in the society of Kolkata. They demonstrated their glory with colorful dress and shoes. People looked I them within tribute'. At present day the social situation in Bangle looked same. People feel proud to perform English in public place mentally. Sunil Gangopadhyan, Indian Bengali poet and novelist, depicted the diglossic situation of Bengali sadly, At present I notice strangely many Bengali people feel inferiority complex within Bengali language and culture. They disregard Bengali badly. We do not speak Bengali every situation and place. We feel proud of if our Children do not learn Bengali language (A-mari-bangla-bhasha). This observation predicated that perhaps Bangladesh is marching on a diglossic situation pragmatically. The trend of diglossia in Bangladesh can be entitled as PARA-DIGLOSSIA. It is also a major reason for the rapid emergence of English language in social function is Bangladesh.

In post-colonial countries including Bangladesh, many prejudices prevail in socio-culture context. LINGUICISM is one of the taboos existing among the colonized people. Linguicism means the belief that one language is superior to other language. The term was coined in the 1980s by linguist Tove SkutnabbKangas. It comes forward to evaluate people by their tongue which is a socio-political prejudice. No land is barren culturally, politically, artistically as well as intellectually. Every native speaker has won culture, tradition, and way of life that build its civilization. Päivi Gynther stated vividly, 'Fundamentally, linguicism is a matter of depriving people of power and influence due to their language (Beyond Systemic Discrimination. Martinus Nijhoff, 2017). Undoubtedly it is LINGUSTIC CHAUVINISM to claim that one civilization is superior to other. One language is superior to other, and one race is superior to other. Tove SkutnabbKangas made parallels between hierarchisation on the basis of racism, ethnicism and Linguicism, Linguicism is the belief or attitude; besides linguistic imperialism is the action of domination language on dominated language. Discrimination based on race, gender or language is regarded as the violation of human rights. No language speaker can consider other language speaker less prestigious then them. There are two sorts of Linguicism; they are intra-linguicism (within the variety of same language) and interlinguicism within two or more different languages). Intralinguicism prescribes that one variety is standard over another variety and thus its insults the existence of local dialects of particular language too. Local varieties are also asset of particular language they must not be insulted or unaccepted inter-linguicism is the psychological arrogant attitude, values and hegemonic beliefs that the language of dominating country is superior to dominated country.

The moment against Linguicism is labeled as LINGISTIC HUMAN RIGHTS. Robert Phillipson (1998) defined, Linguistic human rights are a set of edemas and principles that are ascribed universal validity and interlinked with democracy freedom and popular representation in the political process. Linguistic human right is marketed globally, but need to be discussing if they do not apply to the entire world's language'. In Bangladesh, the medium of education should be assigned in native language with native verity. It is the right of every individual to get the change of 
education in their native language with native variety. There are many tribes in Bangladesh who have own linguistic identity; and thus written from of their education needs to be formed which will help them to full fill their linguistic human rights. Spanish linguist, journalist and literary critic Fernando Lazaro Career stated, ' $A$ natural language is the archive where the experiences knowledge and beliefs of a community are stored'. So, if we violate the linguistic rights of tribal people, it will be a threat on their experiences, knowledge and belief's virtually.

\section{CONCLUSION:}

In Short, the impacts of English over post colonial countries including Bangladesh are vivid by the above discussion. To get rid of linguistic imperialism as well as to upright linguistic human rights, there are some responsibilities of post-colonized people as well as language policy makers. Every language is unique, resourceful as well as identity bearer. No language is superior or in inferior to another language. We have to keep in mind that language does not make knowledge. The Knowledge and economic power of speaker of particular language speaker make the language powerful. Some Suggestions for the future language policy and English teaching of post-colonial counties are given herewith.

1. 'Linguistic Human Right' should be kept in mind to sustain individual's linguistic right. Opportunities need to be given to nurture mother tongue in social and educational field.

2. Language policy makers have to think Linguicism as racialism. Language Policy name's have to think Linguicism as racialism. Language Policy and implication act must be free from Linguicism because Linguicism is a cause to Linguistic Human Right.

3. Local ELT (English Language Teaching) Practitioners need to develop their own ELT materials where local linguistic features will be reflected. This study thinks that is will help the local leaner's to adopt second language successfully as condiment.

4. Linguistic democracy is a new phenomenon in sociolinguistics that can be a panacea to be accepted in local English learning countries. It will also make democratic rights to young leaner's contribute in the field of development cycle of any particular language like English.

5. ELT Practitioner should be aware of the domination of the culture of dominated countries. It is very necessary at present to develop and include the features of local culture in ELT materials.

6. Cultural hegemony should be stopped in the field of second language acquisition. EIT teacher should be concerned about their learners no to adopt the foreign cultures, customs, practices which are contradictory to local culture and national views and ideology.

7. Learners and teachers need to think that English is not learned for the native speaker's superiority but a way to their (local People) admitting equal status in global communication.

8. The history and civilization of local or indigenous people needs to be included in ELT curriculum of Post-colonial countries to demolish linguistic hegemony and in ferocity complex.
9. Local phonological features and varieties should be given prestige in intra-national and international communication. Because it is essence of sound of local people that cannot be insult and should not be uprooted at all.

10. The relation and interrelation within language and nationalism is very sensitive. Sometimes language determines identity of any particular people as well as language community. If a language community considers second language or the language of dominant people, there is a possibility to think it as diglossia. So, ELT material developers need to be concerned about exaggerated importance and appreciation of second language.

11. To make an emergence of local variety of English, free from the domination of native English speakers and agencies are must.

12. De-nationalized English is a challenge for local ELT practitioners of post-colonial countries as well as learners. To adopt this. ELT practitioners and learner should confident and sophisticated on their individual varieties.

13. To evaluate English language proficiency, post-colonized people still depend on the exam system of colonizer. This is also a fact of imperialism. Local testing system of English language in post colonial countries is need to be developed to evaluate English language proficiency test accumulating local varieties which will be free from the linguistic domination.

14. To establish local variety of English by post colonized people; publication writhing and literary works are must. Literature and publication by the features of local varieties can make it established globally.

15. Unnecessary adopting and boring foreign words within the native language is a tense of language suicide. E.I.T practitioners and second language learner need to be concerned about language suicide. It is often seen that young adults unexpectedly use foreign diction with arrogance they also consider this practice as smartness or tread and fashion. Most of Bangladesh Young adults used English greeting and slang in Public Communication as a sign of smartness leaving their native tradition and manner. These types of special expressions appear to them very lubricate and gradually be adopted replacing local expressions. In consequence, language suicide occurs in post-colonial countries.

\section{REFERENCES}

[1] Atmacharit (Autobiography) in Bengali by Sivanath Sastri.

[2] Biography appended to the History of the Brahmo Samaj by Sivanath Sastri

[3] World Englishes: Critical Concepts in Linguistics, volume-5 ; By Kingsley, Braj B Kacrhru.

[4] Rights to Language; Equity, Power and Education; edited by Robert Phillipson.

[5] Päivi Gynther, 'Beyond Systemic Discrimination', Martinus Nijhoff. 2007

[6] Phillipson, R.H.L. (1992), Linguistic Imperialism, Oxford: Oxford University Press.

[7] Crystal D. (1997), English as a Global Lamgauege. Cambridge: Cambridge University Press.

[8]

[9] D.O. Monnoni, 'Prospero and Caliban: The Psychology Colonization'.

[10] Oxford Handbook of Sociolinguistics (2013) by Robert Beyley, Richard Cameron and Seil Laucs. 


\section{AUTHORS}

First Author - Abdul Awal 